\title{
Research on analyzing the impact of Brexit
}

\author{
Junjie Cao \\ College of Arts and Sciences, Stony Brook University, NY 11794, US \\ caojunjie1705@163.com
}

Keywords: Brexit, Globalization, Economic implication, European Union, Countermeasures

\begin{abstract}
The establishment of the EU is conducive to the stability of Europe, to promote the economic development of member countries, to improve the international status of Europe, and to have a significant impact on changes in the world pattern. Since the establishment of the EU, not only the EU member states have been rapid development, but also the global economy has been promoted. Britain as one of the members of the European Union, the British exiting from the EU indicates that the entire EU political, economic, diplomatic pattern will be dramatically changed, the Brexit means that the disintegration of the EU will also have a huge impact on the global economy. This article analyses the impact of the Brexit on the global economy.
\end{abstract}

\section{Introduction}

June 23, 2016, the result of British referendum was announced the British will exit out of the EU. As China and the United Kingdom have close cooperation in a number of areas, on the one hand, China is fourth trading partner of the Britain. By the end of 2014, the UK had more than 7,000 direct investment projects to China, with a total investment of US \$ 20 billion. On the other hand, the UK was also the second largest trading partner of China in the EU. Britain as the world's most important financial center, after leaving from EU, its international status and impact will be greatly reduced.

Brexit is a commonly used term for the United Kingdom's intended withdrawal from the European Union and it process on March 29 in 2017. Brexit brings the UK some political and economic advantages and disadvantages at the same time, which is fully analyzed as follows.

The reason of Brexit

After Brexit, the cause of the British exiting from the EU is fiercely discussed, there are three main points: independent sovereignty, economic drag theory and social security theory. Among them, the independent sovereignty theory is based on the history of the British into Europe, as a veteran power, the United Kingdom after the establishment of the EU eight years ago joined the European Union, and after the United Kingdom joining the EU, it lost $60 \%$ of the legislative power and other sovereignty, and the EU Immigration policy has led to many problems in the UK, many people think that Britain should have independent sovereignty; economic drag theory refers to the British economy after the 80s faster than other countries in the EU, but the United Kingdom each year has to pay the EU relative to other allies higher fee. The EU has become the burden of further development of the British economy. For the social security theory, the main view is that the Middle East war broke out in the past two years and intensified, a large influx of Syrian refugees into Europe, many British citizens are worried that terrorism will be mixed into the UK to endanger social order [1].

The social inequality and social differentiation in the process of globalization and European integration are the more profound economic and social roots of the Brexit. In the context of globalization and integration, the free movement of finance, trade and labor and capital increased the level of economic and social development, which has also exacerbated economic and social inequality. The results of globalization are not evenly distributed among different classes. Technological innovation and financial capital flows will be more conducive to the elite and young people who adapt the market, and those elderly groups who rely on social redistribution mechanism 
are placed in a disadvantageous position, which requires the strengthening of the role of the state in the social distribution and society egalitarian. But "the modern state was torn by the world market and local society, the ability to intervene social distribution is declining." [2] The rift between economic and nationalized societies has led to the rise of anti-elite and anti-formed extremist political parties around the world, which advocated populism and called for a return to isolated national state.

\section{The effect of Brexit on UK}

\subsection{The benefits of Brexit for UK}

First, for the benefits, Brexit can help the UK save billions of pounds of membership fee every year, which reduces the burden for the British government. Second, the UK will collect all the power back from the EU; thus, the UK can make the new international trading policy with other countries for its own interests rather than have to obey the policy from the EU. Third, UK can have its own policy on immigrant issue rather than have to accept immigrants from the EU [3-4].

Brexit can help UK save a lot of member fee because UK averagely pays one eighth of EU budget every year and last year, UK paid 13 billion pounds for EU budget (2016, Week). Right now, UK have left EU; thus, this amount of money can be put in the UK government budget, which can boost the economy of UK in the different ways. First of all, UK government can increase its government spending, which means that the demand of the market is increasing and which will lead to the increase in the supply of the market. Because of the more demand, companies in the UK will expand their business and provide more job positions to people. Companies expand their business can increase the business activities of the whole market and help all kinds of companies grow. Meanwhile, more job position provided can reduce unemployment and increase personal transactions because the more people have income, the more personal transaction can be afforded. In addition, if the government of UK use this amount of money to increase the social benefits for its citizens, the economic burden of the people will be reduced and people will be more willing to spend their money. Thus, the demand of the mark will increase and the supply will increase as well to reach the equilibrium of the market, which will boost UK's economy.

Besides saving member fees, UK will have more freedom on international trading as well. It can directly process trade negotiations with other countries such as China and Indian to gather more benefit for UK, instead of under various constraints benefits for the EU. Also, UK will not have to pay the international students from EU. For example, in 2015, UK accepted 71,000 college students from EU and it consumed a big amount of student loan. And usually these loans will not be paid in a relatively short time. After Brexit, UK can use this amount of money saved to help British students or use it in academic research for British academic field. On immigration policy, more autonomy will be holding by UK after Brexit. The UK doesn't have to accept a huge number of immigrants from the EU. In 2015, there were more than fifty percent of total immigrants from the EU. The increasing number of immigrants took up a large amount of common resources, social welfares and working opportunities for the original British. In a certain extent, the UK has to accept these immigrants from EU with limited conditions due to the EU's common immigration policy. Furthermore, from economic perspective, the rapid increasing immigrants will increase the demand for all products. In a short time, there will be no large increase on supply, so the un-equilibrium will cause the price level increase largely and there will be a great unexpected inflation rate thus this will hurt the stability of current economy. After Brexit, the UK can set up its own restriction policy to decrease the number and increase the ability of immigrants so that UK can better benefit the British on immigration issue [5].

\subsection{The negative impacts of Brexit on UK}

Brexit may decrease the exportation of the UK because the UK lost all the advantages of trading with the countries included in the EU. In addition, Brexit will also hurt the financial services 
industry of the UK because Brexit will bring more regulations and barriers for UK companies' international financial services.

Brexit may bring the UK some economic and political benefits. However, there are negative impacts of Brexit. First of all, the UK will have a great loss of its export market in a short period because Brexit will hurt the exportation from the UK to the EU which is the UK's major business partner. In addition, UK leaving EU will endanger UK's financial services industry because Brexit will increase business cost for UK's financial industry to do business in Europe [4].

"Official trade statistics show that the European Union is the destination for about half of all British goods exports" (The Economic impact of 'Brexit"). EU and UK have many agreements. According to these agreements, 63\% exported goods of the UK shipped to the European Union member countries. Therefore, after the Brexit, it will affect the UK to the overall exportation. Loss of a major export market is a major negative consequence. The UK is a small island economy. International trading to the EU composed 60\% of the UK's economy in 2015. For the UK's trade, $50 \%$ of imports and exports come from the EU; thus, the EU is a major trading partner of Britain. The decrease of the exportation will cause that the export goods have to be sold inside the country, which means that the total domestic supply will increase dramatically. However, the demand does not increase, which will cause huge surplus. Based on this result, the companies in the UK have to decrease their production and cut the job positions. In the end, the GDP of the UK will be decreased.

In 2012, London financial technology industry attracted foreign investment of nearly 700 million pounds, operating income of 6.6 billion pounds, and these numbers are more than California and New York financial centre. After Brexit, these numbers might decrease. The future of the UK's financial industry is not optimistic. 8-10\% of the UK's economy are built by the Financial services. London is a major centre for international business and commerce and is one of the three "command centres" of the global economy. There are over 500 banks with offices in London, and it is the leading international centre for banking, insurance, Euro bonds, foreign exchange, trading and energy futures. Investors in all over the world consider the UK as the access of the EU market. After the Brexit, this access is no longer exist; at the same time, investor will take their capital back and find another way to get into the financial market of the EU. in addition, there will be more regulations for the UK's financial companies to run business in the EU. The increasing business cost will reduce the profits of these companies. Meanwhile, because of these regulations, these financial companies will lose lots of their customers in the EU. Overall, because of the Brexit, the financial industry of the UK will no longer thrive and the economy of the UK will be influenced as well [5].

\section{The impact of Brexit on global economy}

Brexit is like a "black swan event", its impact on the world's political and economic is uncertain, it is more difficult to get the exact result in advance. In the day of Cameron government issued the referendum the results, the international financial markets have been hit violently, this is the panic reaction of the global economy against the Brexit. In addition, for the foreign exchange rate, the dollar, the yen exchange rate rose sharply, while the exchange rate of other currencies has declined, the pound declined rate as $8.9 \%$ was in the first place, which made the new records of more than 30 years in British; global financial markets simultaneously declined, MSCI global stock fell by 4.9\%. Britain, Germany, Japan and other countries of the national debt income is significantly reduced. In addition, gold prices rose sharply, while other commodity prices showed a downward trend. Analysis from the UK's domestic situation, some people expressed dissatisfaction with the results of this referendum, claiming to go back and ask for re-referendum. From the EU analysis, even if the British exit from the EU, it also need to go through a period of negotiations. From the analysis of the world pattern, the Brexit become an irreversible fact, the world pattern will be changed dramatically [6]. 


\subsection{The global economy has been hit hard}

The first effect of this referendum is the British economy, the national economic growth rate, price, employment, foreign investment and the status of London in the international financial market will be seriously affected as well. The degree of influence is determined by the form between Britain's post-European and EU economic trade. From the social industry analysis, the impact of the British financial industry is most serious, and the status of London in the international financial market is impacted as well. About $40 \%$ of the global foreign exchange market transactions happened in the United Kingdom, and many headquarters of the large financial organizations or institutions of the EU were built in London. For the EU countries, many financial products trading and risk aversion activities are mostly carried out in the UK; The percentage of the United Kingdom in the EU finance market activity is more than $80 \%$, and about $75 \%$ of European capital assets are distributed in the UK. Brexit led to a number of financial activities of EU will be adjusted, and the EU large financial institutions and organizations will be transferred to other countries, which give a significant impact on the British financial sector.

\section{2. "Imitation effect" will accelerate the global economic instability}

Brexit will expose more conflicts and contradictions of EU. The outbreak of the EU debt crisis in 2012, gradually exposed the political defects, that is, there is no adjustment between unified currency and decentralized financial system. Brexit is mainly due to the lack of co-ordination between responsibility and interests, and there is a big difference between the political philosophy with other EU countries. After Brexit, there were problems of independence in England and Ireland, and in other EU countries the "imitation effect" led to a series of problems. According to the survey, Greece, Italy, France and Portugal and other countries have the leaving-European will, and the public survey shows that people support exit from EU more than $40 \%$ in other EU countries, if these countries imitate the British referendum, the public support rate is a great chance of more than $50 \%$. These problems will accelerate the disintegration of the EU.

\subsection{The international political situation will face adjustment}

At present, the world pattern presents multi-polarization development, but under the influence of the Brexit, the multi-polar world pattern will face change. In some countries, the development of Nazism is rapid and the international political situation is confusing. After Brexit, the EU as a world leader in the political situation, the strength will be greatly reduced, the right to speak for international affairs also decline, which has a serious impact on dealing with the Syrian issue, the Iranian nuclear issue, the DPRK nuclear issue, to combat terrorism. Russia, as the leader of the world's multi-polarization pattern, is geographically close to the EU and has been strongly dissatisfied with the expansion of the EU and continue to attract new members relying on NATO, which may catch this opportunity to weaken the EU's international status to get better international status.

\section{Conclusion}

In general, Brexit is like a double-edged sword. After Brexit, UK saves a large amount of member fee every year, also, UK has the right to set up the policy only for its own benefits such as international trading and immigration issues. On the other hand, Brexit also brings negative impact for UK. The export trade has been affected and the financial services will be hurt due to the new regulation and barriers for UK's companies. Historically, Brexit is the first time that member country votes to leave the union, we cannot easily tell if it is a wise move or not for British people, but we can use economic tools to analyze the pros and cons from economic aspect to predict the economic influences more precisely. 


\section{References}

[1]. Battistella D Theories des relations internationals [M] Social Sciences Academic Press, 2010.

[2]. Li JC Brexit: background, appeal and outlook [J] The Contemporary World, 2015, 9: 34-35.

[3]. Jackson JK, Akhtar SI Possible economic impact of Brexit [R] Congressional Research Service Reports, 2016.

[4]. Somerville $\mathrm{W}$ When the dust settles: migration policy after Brexit [N] Migration Policy Institute, Dec. 2016.

[5]. Brexit [N] The Week UK, June 2016.

[6]. Wang L A hierarchical analysis of the impact of Brexit [J] Communication Between China and Foreign Countries, 2016, 24:24-25. 